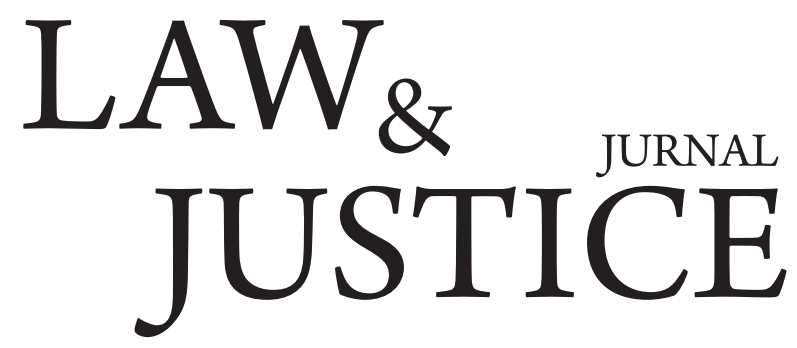

Volume 4, Nomor 1, April 2019

\title{
Profesi Notaris di Era Industrialisasi dalam Perspektif Transendensi Pancasila
}

\author{
Aris Yulia \\ Mahasiswi Program Doktor Ilmu Hukum Universitas Diponegoro \\ Email: Aris_yulia@yahoo.com
}

\begin{abstract}
Abstrak
Notaris merupakan pejabat publik yang memiliki peran sangat besat dalam mengakomodasi perbuatan hukum sesuai dengan yang sudah diatur dalam UU Nomor 2 Tahun 2014 yang dilakukan oleh masyarakat sesuai dengan tuntutan zaman. Notaris dapat dikatakan sebagai profesi pejabat yang membuat dokumen tekuat dan terpenuh dalam pemenuhan bukti secara otentik atau sempurna yang dilakukan untuk proses penegakan hukum. Notaris dalam menjalankan profesinya diwajibkan untuk menyesuaikan dan mengikuti perkembangan di era globalisasi dikarenakan keterkaitannya mengenai hal - hal yang menyangkut tentang perdata seperti transaksi-transaksi yang terjadi dan dilakukan melalui sarana elektronik dan banyak dilakukan secara online, serta semakin banyak mengalami perkembangan dan saling terintegrasi satu sama lainnya, sebagai contoh adalah hubungan antara Kementrian Hukum \& HAM yg terintegrasi dengan Kementrian Koordinator Bidang Perekonomian, hubungan ini terintegrasi melalui sistem perizinan terbaru yaitu OSS (Online Single Submission) sesuai dengan PP Nomor 24 Tahun 2018. Kemajuan informasi yang berkembang pesat ini bisa menjadi bumerang sekaligus menjadi tantangan tersendiri bagi keberadaan dan eksistensi notaris. Terdapat aturan yang diwajibkan dituangkan dalam bentuk akta notaris, dan jika hal ini tidak dilaksanakan atau tidak dituangkan dalam bentuk akta yang dibuat oleh notaris, maka kegiatan dan/atau transaksi itu dianggap tak memiliki kekuatan hukum. Ini menunjukan terdapat hubungan hukum antara keperdataan di masyarakat dengan notaris, termasuk hubungan dalam bidang ekonomi. Dengan demikian akan menimbulkan permasalahan bagaimana kedudukan hukum atas akta notaris dalam perizinan usaha terbaru bagi dunia kenotariatan?
\end{abstract}

Keywords: Profesi Notaris, Era Transedental, Transendensi Pancasila, OSS.

\section{Pendahuluan}

Pancasila merupakan sumber nilai tertib hukum dan juga merupakan sumber norma moral dalam pelaksanaan hukum suatu sumber norma moral bagi pelaksanaan hukum di Indonesia dalam penyelenggaraan bernegara dan berkebangsaan. Norma etika dan norma moral sebagaimana yang terkandung dalam Pancasila juga harus menjadi landasan formal bagi pelaksanaan dan penyelenggaraan negara. Berdasarkan pembukaan UUD 1945, dapat dikatakan bahwa demi melindungi seluruh kehidupan bangsa dan tumpah darah Indonesia, serta memajukan kesejahteraan umum dan mencerdaskan kehidupan bangsa, dan juga ikut dalam melaksanakan ketertiban dunia 
berdasarkan kemerdekaan, perdamaian abadi, dan keadilan sosial merupakan tujuan utama dari Negara Republik Indonesia. Komponen utama yang harus terpenuhi dalam rangka untuk mewujudkan kesejahteraan semua wara negara demi tercapainya kepastian hukum dan terpenuhinya kebutuhan atas barang dan jasa. ${ }^{1}$

Menciptakan kepastian hukum merupakan bentuk dan peran bagi notaris, dan juga sebagai bentuk pemenuhan hidup bagi semua warga negara. Peran notaris sangat besar dalam mengakomodasi mengakomodasi dan menciptakan kepastian hukum dalam perbuatan hukum yang dilakukan untuk memenuhi kebutuhan hidup bagi semua warga negara sesuai dengan tuntutan zaman. Terjadi peningkatan intensitas dan kompleks dalam hubungan hukum terkait dengan pekembangan kehidupan masyarakat, sehungga membutuhkan adanya perlindungan hukum serta kepastian hukum terkait alat bukti untuk dapat membedakan antara hak dan kewajiban secara jelas dari subjek-subjek hukum yang ada. Kegiatan pengadminstrasian hukum (law administrating) yang tertib dan tepat dapat menciptakan perlindungan, kepastian dan ketertiban hukum. Hal ini berguna demi mencegah hal-hal yang mengakibatkan adanya cacat hukum yang dapat membuat masyarakat dan subjek hukum dirugikan.

Fungsi profesi notaris sebagai pejabat umum sangat dibutuhkan keberadaannya sebagai tempat bagi masyarakat untuk memperoleh nasihat serta segala sesuai yang ditulis dan ditetapkan oleh notaris (konstatir) adalah benar. Serta dapat dikatakan bahwa seorang notaris merupakan pembuat dokumen terkuat dan memiliki sifat pembuktian yang sempurna dalam suatu proses penegakan hukum. Perkembangan era globalisasi menerjang semua negara, dan perkembangan ini menuntut agar para notaris senantiasa up to date dalam perkembangan tentang media teknologi yang terbaru dikaitkan dengan keperdataan. Perkembangan era globalisasi dalam hal krisis keuangan global merupakan topik isu utama di seluruh belahan dunia yang terjadi sejak tahun 1997, dan hal ini terjadi hingga sampai saat ini, dan notaris dituntut untuk menghadapi tantangan perkembangan era globalisasi tersebut. Globalisasi yang menerjang semua negara hingga saat ini

1 Definisi Pengertian Kesejahteraan Rakyat, http://www. definisi-pengertian.com/2015/05/definisi-pengertiankesejahteraan-rakyat.html, diakses pada 25 Maret 2019. masih dirasakan oleh lembaga profesi hukum di Indonesia, khususnya mengenai idealisme dan martabat profesi notaris. Di satu sisi, notaris dituntut untuk menjaga idealism sebagai pejabat umum sebagaimana yang diamanatkan dalam Pasal 3 ayat (7) Kode Etik notaris serta diamanatkan juga dalam Pasal 37 Undang-Undang Nomor 2 Tahun 2014 tentang Perubahan atas UndangUndang Nomor 30 Tahun 2014 tentang Jabatan Notaris (yang selanjutnya disebut dengan UUJN), dan disisi lain notaris didesak oleh kebutuhan materialisme untuk memenuhi kebutuhan hidup dan biaya operasional demi eksitensi kantornya.

Notaris memiliki kewenangan dalam membuat akta otentik untuk semua perbuatan, perjanjian, dan menurut ketetapan yang diharuskan sesuai dalam peraturan perundang-undangan dan/ atau apa yang dikehendaki oleh mereka yang berkepentingan untuk dinyatakan/dicantumkan dalam akta otentik, untuk menjamin kepastian tanggal pembuatan akta, menyimpan akta, memberikan grosse, salinan, dan kutipan akta. Hal tersebut diatas sesuai dengan ketentuan dalam Pasal 15 ayat (1) UUJN. Namun hal tersebut juga tidak dikecualikan juga kepada pejabat atau orang lain sebagaimana ditetapkan didalam undangundang. Serta notaris juga berwenang untuk mengesahkan tanda tangan dan juga menetapkan kepastian tanggal surat yang dilakukan dibawah tangan dengan mendaftarkannya didalam buku khusus.

Teknologi dan informasi telah mengalami kemajuan dan perkembangan yang signifikan sehingga bersifat bumerang sekaligus juga tantangan untuk eksistensi di dunia profesi notaris. Dengan demikian, hal tersebut menjadikan segala transaksi diubah dalam bentuk paperless demi efisiensi dan bernilai ekonomis, disamping itu terdapat juga beberapa syarat yang tidak bisa dihilangkan secara keseluruhan untuk tetap mempergunakan kertas sebagai bentuk/alat bukti tertulis bahwa telah terjadi suatu perbuatan hukum, yaitu berupa pembuatan akta yang dibuat dihadapan notaris yang menjadikan alat bukti tertulis tersebut menjadi akta yang bersifat otentik.

Peran notaris sangat penting bagi kehidupan masyarakat, hal ini dikarenakan banyaknya masyarakat yang membutuhkan peran notaris demi kepentingan melakukan transaksi dalam dunia bisnis. Diantaranya yang berkaitan dengan ketentuan-ketentuan yang mewajibkan dibuatnya 
akta oleh notaris, dan jika hal ini dilakukan tanpa adanya akta yang dibuat oleh notaris, maka dengan demikian transaksi itu dianggap tidak memiliki kekuatan di mata hukum. Hal tersebut menunjukan adanya suatu hubungan yang besar antara notaris dalam hal keperdataaan maupun hubungan ekonomi didalam kehidupan masyarakat. Hubungan keperdataan dari sebuah transaksi yang melibatkan notaris ini memiliki nilai kemanfaatan yang besar yang ditentukan dalam peran notaris tersebut. seperti data berupa dokumen yang berbentuk elektronik seperti e-commerce yang membutuhkan peran keterlibatan bagi para pemegang kepentingan yang terkait, yaitu diantaranya negara, notaris dan masyarakat itu sendiri. Dilihat dari permasalahan latar belakang tersebut diatas, maka perlunya dilakukan suatu pengkajian lebih mendalam mengenai bagaimana perihal kedudukan hukum mengenai akta notaris yang dikaitkan dengan perizinan usaha terbaru bagi dunia kenotariatan?

\section{Metode Penelitian}

Penelitian ini menggunakan metode pengumpulan data pustaka, yakni mengumpulkan data-data yang bersumber dari buku-buku, karya ilmiah, perundang-undangan dan juga dokumen dan juga beberapa bahan dari sumber hukum lainnya berkaitan sesuai dengan tema dan topik penelitian ini. Teori yang digunakan dalam menganalisis penelitian ini menggunakan teori bekerjanya hukum yang digagas oleh Chambliss dan Seidman. Menurut teori Chambliss dan Seidman ini, pembentukan dan implementasi hukum tindakan pernah terlepas dari asupan atau pengaruh kekuatan sosial dan personal, terutama pengaruh dari sosial politik. ${ }^{2}$ Terdapat tiga unsur yang terkandung dan mempengaruhi tatanan dan ketertiban yang berlaku dalam masyarakat dalam teori bekerjanya hukum, yakni: Rule making of institution, dalam penelitian ini adalah Kementrian Koorinator Bidang Perekonomian dan Badan Koordinasi Penanaman Modal; Rule making of sanction, dalam peneltian ini adalah Kementrian Hukum dan Hak Asasi Manusia melalui DitJen AHU; dan Role occupant, dalam penelitian ini

2 Lihat Robert B. Seidman dan William J. Chambless, Law, Order, and Power, printed in United States of America, Published Stimulant in Canada Library of Cobress Catalog Cars No.78-111948. adalah Notaris dan para pengguna jasa notaris yang berkaitan dengan badan usaha.

\section{Hasil dan Pembahasan}

Revolusi industri 4.0 yang melanda dunia millenial memberikan tantangan pada semua pihak termasuk profesi hukum yang mengharuskan memunculkan kreativitas untuk menjawabnya. Di bidang profesi hukum terjadi juga pergeseran akibat revolusi industri 4.0 yang merupakan tantangan untuk merespon persoalan yang akan datang. Keterbukaan terhadap sains dan teknologi bagi kalangan hukum tidak dapat dihindari, sehingga revolusi industri 4.0 membantu percepatan dalam bidang administrasi, pengarsipan dan pengiriman data. $^{3}$

Dilihat dari history, notaris merupakan pejabat umum negara yang dilantik oleh Menteri Hukum dan Hak Asasi Manusia untuk menjalankan dan melaksanakan peran dan fungsi yang ditentukan oleh negara untukmelakukanlayanankepadaumum untuk masyarakat agar tercapai dan terciptanya kejelasan secara hukum yang berkaitan dengan hal keperdataan dalam kapasitasnya sebagai pejabat pembuat akta otentik. Yang dimaksud dengan akta otentik seperti yang dinyatakan dalam Pasal 1868 Kitab Undang-Undang Hukum Perdata adalah suatu akta yang dibuat dalam bentuk yang telah ditentukan oleh undang-undang atau dihadapan pejabat umum yang berwenang untuk itu ditempat akta itu dibuat. ${ }^{4}$

Pasal 1 UUJN merupakan peraturan perundang-undangan yang berisikan pengertian mengenai notaris yang tercantum bahwa yakni Notaris merupakan suatu jabatan umum yang bertindak dalam pembuatan akta yang bersifat otentik serta memiliki tugas lain seperti yang tercantum dalam peraturan yang terkait tersebut. ${ }^{5}$ Dapat dinyatakan bahwa fungsi dari notaris adalah menetapkan hubungan dalam hukum antara para pihak yang terkait dalam bentuk tertulis dan format tertentu, sehingga menjadi bentuk sebuah akta otentik. Notaris merupakan pembuat

3 Liliana Tegjosaputro, Tantangan Praktek Kenotariatan dalam Menghadapi Revolusi Industri 4.0, bahan ajar Universitas 17 Agustus 1845, Semarang.

Pasal 1868 Kitab Undang-Undang Hukum Perdata.

5 Pasal 1 Undang-Undang Nomor 2 Tahun 2014 tentang Perubahan atas Undang-Undang Nomor 30 Tahun 2014 tentang Jabatan Notaris. 
dokumen yang kuat dalam suatu proses hukum. ${ }^{6}$ Pembuatan akta otentik yang dilakukan oleh notaris baik berupa relaas acten maupun partij acten diharuskan mengandung unsur objektivitas. Selain notaris, yang diberi tugas dalam pembuatan akta yang bersifat otentik, adalah Pegawai Catatan Sipil serta pemangku jabatan lainnya mempunyai tugas dan wewenang dalam melakukan pembuatan akta yang bersifat otentik yang disebut sebagai pejabat umum.

Notaris memiliki kewenangan untuk membuat suatu bentuk dokumen yang berbentuk akta, baik akta notaril maupun akta dibawah tangan. Hal ini dapat dikatakan hanya berupa sebahagian dari keseluruhan tindakan hukum yang berada diranah privat yang terjadi di masyarakat yang berfungsi sebagai pembuktian yang mempunyai kekuatan hukum yang sempurna. Jika dilihat melalui ketentuan Pasal 5 ayat (4) Huruf b UndangUndang Nomor 11 Tahun 2008 tentang Informasi dan Transaksi Elektronik (selanjutnya disingkat dengan UU-ITE), memberikan penjelasan mengenai pengharusan pembuatan akta yang berbentuk dokumen sesuai dengan bentuk akta yang bersifat otentik dan sesuai dengan ketentuan yang diberlakukan dalam undang-undang ini yang ditulis dan tertuang dalam bentuk akta notaril. ${ }^{7}$

Terdapat keterkaitan dalam bidang hukum diantara fungsi notaris, fungsi dan tujuan UUITE, serta makna dari pendatanganan akta, yang tercantum didalam sebuah pernyataan dari keseluruhan transaksi yang bersifat elektronik, dan dapat dianggap sebagai suatu akta, dan juga pembuktian terhadap hal ini sama seperti akta otentik. Implikasi antara keterlibatan hukum antara fungsi notaris, fungsi dan tujuan UU-ITE, serta makna dari pendatanganan akta tersebut berada pada beban pembuktian yang ada pada tanda tangan yang bersifat elektonik. Penerapan penandatanganan yang bersifat elektronik juga bisa dilakukan di Negara Indonesia, akan tetapi hal ini belum dapat dilakukan terhadap surat penting yang sah secara hukum, sebab beban pembuktian keabsahan akta tersebut berada pada tahapan pengesahan yang mustahil untuk mengubah dokumen yang bersifat elektronik menjadi akta yang bersifat otentik, meskipun

6 Tan Thong Kie, Studi Notariat, Beberapa Mata Pelajaran dan Serba-Serbi Praktek Notaris, Jakarta: PT Ichtiar Baru Van Hoeve, 2007, hlm 159.

7 Lihat Undang-Undang Nomor 11 Tahun 2008 tentang Informasi dan Transaksi Elektronik. dokumen elektronik tersebut sebagai akta dibawah tangan. Berdasarkan Pasal 1320 Kitab UndangUndang Hukum Perdata, legalisasi terhadap e-commerce merupakan sah, karena perikatan yang dilakukan secara elektronik yang melalui perantara elektronik yang adalah berupa perikatan yang dilakukan secara bebas, baik tertulis ataupun lisan pada dasarnya telah dilakukan sebagaimana yang telah diatur dalam Pasal 1320 KUH Perdata. Jika melihat ketentuan Pasal 164 HIR, akta atau dokumen elektronik dapat dijadikan sebagai alat bukti tertulis, hal ini dikarenakan telah memenuhi persyaratan perjanjian sebagaimana yang telah diatur dalam KUH Perdata.

Kendala yang dihadapi oleh notaris dengan adanya tanda tangan elektronik untuk dijadikan sebagai alat bukti, dokumen elektronik tersebut harus dinyatakan dengan sah serta tepat dengan yang aslinya yang sudah ada terlebih dahulu. Pembuktian dokumen elektronik sebagai alat bukti agar memiliki kekuatan hukum serta kekuatan pembuktian yang tidak terbantahkan, maka harus disertai dan dibarengi berupa suatu bukti petunjuk keterangan dari ahli. Diperlukan pengesahan dan pengakuan dari pejabat yang berwenang diperlukan terhadap segala sesuatu yang mempunyai hubungan dan kaitan dengan dokumen informasi dan transaksi yang bersifat elektronik tersebut harus sesuai dengan bagaimana bentuknya yang asli, meskipun didalam persidangan tidak dapat diperhadirkan. Arrianto Mukti Wibowo ${ }^{8}$ dalam makalahnya menyataka bahwa keaslian tanda tangan elektronik dapat langsung ditentukan atau dapat langsung diketahui didalam pengadilan. Hal ini dikarenakan adanya Penyelenggara Sertifikasi Elektronik (Certification Authority) yang merupakan lembaga keterkaitan infrastruktur yang ada diluar para pihak yang telah diberikan lisensi oleh pemerintah untuk menerbitkan tanda tangan elektronik. Terdapat suatu kekhawatirkan terkait keberadaan penandatanganan secara elektronik terhadap dokumen elektronik yang dilakukan sesuai dengan peraturan berdasarkan undangundang yang berlaku, serta sudah mendapat certification authority terhadap akta yang bersifat otentik yang dibuat didepan dan oleh notaris.

8 Arimukti Wibowo dkk, Kerangka Hukum Digital Signature dalam Elektronic Commerce, disampaikan dalam seminar Masyarakat Telekomunikasi Indonesia Pusat Ilmu Komputer, Universitas Indonesia, Juni, 1999. 
Pasal 5 ayat (4) huruf a UU-ITE menjelaskan bahwa segala jenis surat tidak hanya surat berharga saja, namun juga terhadap surat yang dipergunakan dalam menegakan hukum administrasi negara, perdata dan pidana wajib dibuat dengan tertulis berdasarkan undang-undang Terdapat hubungan terhadap ketentuan sesuatu yang diatur dalam UUITE Pasal 5 ayat (4) huruf a serta ketentuan yang diatur dalam Pasal 8 ayat (3) Rancangan UndangUndang Pemanfaatan Teknologi Informasi ${ }^{9}$, yang menegaskan tentang dokumen yang dibuat dalam bentuk elektronik, begitu juga dengan penandatanganan yang dilakukan secara digital dianggap tidak berlaku terhadap:

1. Membuat serta melaksanakan surat wasiat;

2. Perikatan mengenai transaksi suatu barang tidak bergerak

3. Hak kepemilikan yang dinyatakan dalam dokumen

4. Surat berharga terkecuali saham yang diperjualbelikan dalam bursa efek

5. Dokumen lainnya sesuai dengan ketentuan didalam perundang- undangan yang terkait mewajibkan untuk disahkan melalui pejabat yang memiliki kewenangan untuk mengesahkan dokumen atau juga kepada notaris.

Pasal 5 ayat (4) huruf b UU-ITE memberikan penjelasan mengenai pengecualian terhadap kedudukan dokumen yang bersifat elektronik serta ditandatangani secara digital yang tak tergantikan posisi serta fungsi akta yag bersifat otentik dimana proses pembuatannya dilakukan dihadapan Pejabat Umum, pembuatan akta tersebut telah ditentukan dalam perundangundangan ataupun juga akta yang oleh masyarakat dikehendaki. Tidak hanya sebatas itu saja, akta yang dibuat oleh notaris yang dilakukan melalui media teknologi dan informasi juga berkekuatan hukum dan jika dalam pembuatannya dilakukan sesuai peraturan perundang-undangan berlaku, meskipun pengaplikasiannya dilakukan melalui sistem elektronik.

Namun ketentuan tersebut hanya sebuah alternatif atas posisi dokumen yang bersifat elektronik dan juga tandatangan yang bersifat digital yang dilakukan untuk proses membuat dan melaksanakan baik surat berharga, surat wasiat,

9 Lihat Rancangan Undang-Undang Pemanfaatan Teknologu Informasi. dan juga perikatan atas objek barang tak bergerak, surat-surat penting mengenai penunjukan hak atas kepemilikan, dokumen yang bersifat elektronik, serta penandatanganan secara digital yang tidak berkedudukan sama atas surat bukti tertulis lainnya, serta juga penandatanganan secara manual yang dilakukan seperti biasanya. Peraturan perundang-undangan mewajibkan surat dan juga dokumen yang terkait harus dilaksanakan dalam bentuk akta notaris atau akta yang dihasilkan oleh pejabat pembuat akta notaril yang bersifat otentik, kecuali terhadap surat-surat penting yang bersifat elektronik yang menggunakan penandatanganan secara digital. Hal ini ditegaskan dalam Pasal 5 ayat (4) UU-ITE yang menyatakan bahwa surat-surat penting tersebut tidak termasuk surat penting yang dibuat secara elektonik sebagaimana dinyatakan tak bisa dijadikan alat pembuktian yang sah. Ketentuan mengenai surat dan dokumen yang diwajibkan dibuat dalam bentuk akta notaril sebagaimana yang diatur menurut Undang-Undang dan juga dalam ketentuan UU-ITE, kecuali terhadap surat dan dokumen yang ditentukan lain dalam UU-ITE. Ketentuan tersebut tidak akan dapat menggantikan kedudukan dari akta otentik yang dibuat di hadapan atau dibuat oleh Notaris atau Pejabat Pembuat Akta Tanah.

Pasal 5 ayat (4) huruf d UU-ITE yang menyatakan bahwa seluruh surat-surat penting yang tertuang didalam akta notaril, sebagaimana yang ditentukan oleh undang-undang, mempunyai implikasi yuridis terhadap Notaris/ Pejabat Pembuat Akta Tanah. Kata "semua" dalam ketentuan yang ada di Pasal 5 ayat (4) huruf d tersebut memiliki makna bahwa akta otentik tidak hanya sebatas kepada akta otentik yang bentuknya yang telah ditentukan oleh undang-undang saja, namun juga dalam bentuk apa yang dikehendaki oleh masyarakat atau para pihak yang terdapat didalam akta selama pernyataan tersebut dibuat dalam bentuk akta otentik yang bentuk nyatanya dibentuk dan dibuat dengan menggunakan media cetak, serta non-elektronik juga, melainkan terhadap akta yang dibentuk dihadapan dan dibuat oleh notaris yang berfungsi untuk dijadikan akta yang bersifat otentik seperti yang tercantum dan diatur dalam undang-undang, yakni akta pejabat (relaas acten) dan akta para pihak (patij acten). Wewenang penuh sebagaimana yang dinyatakan dalam Undang-Undang Nomor 2 Tahun 2014 tentang Perubahan Atas Undang-Undang Nomor 
30 Tahun 2004 tentang Jabatan Notaris yang dimiliki oleh seorang Notaris untuk membentuk dan membuat akta-akta memiliki kekuatan pembuktianya sempurna. Pembuktian yang sempurna ini dapat dilihat dari keterangan yang dapat diandalkan dan dapat dipercayai, bersifat tidak memihak dan tanda tangan serta segel (cap) yang dibuat oleh Notaris memberikan bukti dan jaminan yang kuat. Ini juga berfungsi untuk melindungi suatu perjanjian yang terlah dibuat pada kemudian hari atau pada saat yang akan datang, hal inilah yang perlu dilakukan seorang Notaris untuk mencegah terjadinya kesulitan yang akan terjadi itu. ${ }^{10}$

Hal tersebut diatas dilakukan terutama dalam membuat akta pejabat (ambtelike akten/ relaas acten) yang hanya dapat ditandatangani oleh seorang Notaris dan memiliki sifat otentik sekalipun tidak ditandatangani oleh para pihak yang ada didalam akta, seperti laporan RUPS, hal ini sesuai dengan pengertian dari kata relass yang memiliki arti bericht verslaas atau laporan (report) atau proses verbal seorang pejabat (written account). Kedudukan Notaris yang tidak hanya sebatas "tukang" atau "juru tulis", melainkan sebagai "pejabat umum" juga memiliki kewajiban untuk menegakkan dan menjalankan prinsip good governance atau general principles of good administration meliputi asas-asas yang mengutamakan: kepastian hukum; kepentingan umum; tertib penyelenggaraan; keterbukaan; efisiensi profesionalitas; efektivitas; dan akuntabilitas.

Penggunaan tanda tangan elektronik sebagaimana yang telah diatur di Pasal 11 UUITE akan berkekuatan hukum serta juga sebagai ketentuan baku dalam mengamankan tanda tangan yang bersifat elektronik diatur didalam ketentuan Pasal 12 ayat (2) UU-ITE, dan kedua hal yang telah dibahas itu adalah suatu tata cara serta mengandung asas kehati-hatian dalam penggunaan surat penting yang berbentuk elektronik. Dan tata cara pelaksanaan dari asas kehati-hatian dalam penggunaan dokumen yang bersifat elektronik ini merupakan alasan hukum untuk melahirkan suatu hak yang dan memperkuat atau juga menolak suatu hak. Namun penolakan dan memperkuat dokumen elektronik jika dikaitkan dengan jabatan profesi notaris dapat menimbulkan permasalahan hukum yang disebabkan oleh kewenangan yang

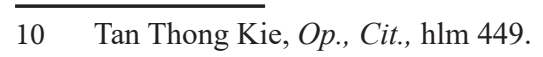

dimiliki notaris secara eksternal mengalami pelemahan yang disebabkan oleh sistem hukum yang berkembang di Indonesia. Sistem hukum yang diterapkan dalam pemerintahan Negara Republik Indonesia adalah tata hukum campuran, yakni campuran civil law, common law, tata hukum Islam, serta Hukum Adat yang membentuk suatu ketentuan yang berbentuk undang-undang. Serta hal tersebut mengakibatkan kemunduran yang dialami oleh lembaga kenotariatan, dan apabila tidak segera ditanggapi atau dibiarkan sampai berlarut-larut oleh para pengurus yang berada di perkumpulan yang disebut dengan Ikatan Notaris Indonesia, dengan demikian, kenotariatan semakin lama hanya menjadi perkumpulan para tukang stempel.

Notaris dituntut untuk mengikuti juga menyesuaikan perkembangan era globalisasi yang terjadi pada saat ini, hal ini dikarenakan adanya hubungan keperdataan yang dapat terjadi transaski yang dilakukan secara media elektronik atau transaksi yang dilakukan secara online, serta semakin banyak mengalami perkembangan dan saling terintegrasi satu sama lainnya, sebagai contoh adalah hubungan antara Kementrian Hukum dan Hak Asasi Manusia yang terintegrasi dengan Kementerian Koordinator Bidang Perekonomian, hubungan ini terintegrasi melalui sistem perizinan terbaru yaitu OSS (Online Single Submission) sesuai dengan PP Nomor 24 Tahun 2018. Pemerintah saat ini menggalakkan suatu kebijakan mempermudah dan mempercepat dalam melaksanakan penanaman modal serta tata cara berusaha yang berlaku di Negara Republik Indonesia. Negara Republik Indonesia mewajibkan suatu program atau sistem, yakni Online Single Submission (OSS), yakni suatu sistem elektronik yang berisikan tentang perizinan berusaha yang diterbitkan oleh lembaga OSS untuk dan atas nama menteri, lembaga, gubernur, atau bupati/wali kota kepada pelaku usaha. ${ }^{11}$ Lembaga OSS merupakan pengembangan dari Pelayanan Terpadu Satu Pintu (PTSP). Sistem OSS ini sudah mulai dibangun sejak Oktober 2017 atas amanat Perpres Nomor 91 Tahun 2017 tentang Percepatan Pelaksanaan Berusaha, dengan diberlakukannya sistem OSS, setiap badan usaha maupun perorangan yang mendaftarkan usaha melalui OSS akan memiliki

11 Lihat Pengumuman Bersama Kementrian Hukum dan HAM RI Cq. Direktorat Jenderal Administrasi Hukum Umum dan Kementrian Koordinator Bidang Perekonomian RI Cq. Lembaga OSS. 
Nomor Induk Berusaha. Sistem OSS yang merupakan pengembangan dari sistem PTSP, akan menginterkoneksikan dan mengintegrasikan sistem Teknologi Informasi dan Komunikasi (TIK) pelayanan perizinan dengan memanfaatkan PTSP. PTSP di tingkat pusat dikelola oleh Sistem Pelayanan Infromasi dan Perizinan Investasi Secara Elektronik (SPIPISE) Badan Koordinasi Penaman Modal (BKPM), sedangkan PTSP di tingkat daerah, menggunakan sistem SiCantik yang dikelola oleh Kementrian Komunikasi dan Informatika. Sistem ini juga didukung oleh sistem dari berbagai kementrian/ lembaga penerbitan perizinan termasuk sistem Indonesia Nasional Single Window (INSW). ${ }^{12}$

Sistem Online Single Submission (OSS) ini pada awalnya akan dipegang kendali oleh Badan Koordinasi Penanaman Modal (BKPM), namun pernyataaan Mentri Koordinator Bidang Perekonomian, Darmin Nasution, menyatakan mengambil peran BKPM pada awal pembentukan sistem OSS dalam urusan perizinan Online Single Submission ini, dengan alasan BKPM menyatakan masih belum siap. Namun pengambil-alihan ini hanya dilakukan pada tahap awal saja dan bersifat sementara, apabila sudah siap, akan dikembalikan kepada BKPM kembali. Hal ini dilakukan berdasarkan kesepakatan antara pihak Mentri Koordinator Bidang Perekonomian dengan pihak BKPM, Kementrian Koordinator hanya mengambil wewenang penyelenggaraan OSS selama enam bulan pertama pemberlakuan sistem OSS, sumber daya Indonesia Nasional Single Window (INSW) akan diberdayakan untuk sementara dalam menjalankan OSS. Hal ini dilakukan sehubungan dengan perintah Presiden Joko Widodo agar program ini diimplementasi, dan hal ini disambut baik oleh Ketua Kamar Dagang dan Industri (Kadin) Indonesia, Rosan Perkasa Roeslani, menurutnya OSS akan menyelesaikan permasalahan izin investasi dari pusat hingga daerah. ${ }^{13}$

12 Simak Ulasan Notaris soal Perbedaan OSS, PTSP, AHU Online dan Sisminbakum, https://m.hukumonline. com/berita/baca/lt5bb4adade $68803 /$ simak-ulasannotaris-soal-perbedaan-oss - ptsp-ahu-online-dansisminbakum diakses pada 25 Maret 2019.

13 BKPM Belum Siap, Kemenko Ekonomi Tangani Izin Online Terintegrasi, https://amp.katadata.co.id/ berita/2018/06/04/bkpm-belum-siap-kemenkoekonomi-tangani-izin-online-terintegrasi diakses pada 24 Maret 2019.
Pada awal telah diberlakukannya sistem OSS, lembaga Dewan Perwakilan Rakyat Republik Indonesia menghimbau agar pemberlakuan tata cara pengajuan izin usaha tunggal berbasis online (OSS) untuk tidak diberlakukan kembali, dengan alasan permbelakuan OSS dianggap menghalangi berjalannya tata cara berinvestasi di Negara Republik Indonesia dan terdapat ketidaksesuaian terhadap bekerjanya OSS itu. Serta kehadiran dan pemberlakuan sistem OSS dinilai terkesan dipaksakan sehingga berdampak negatif dalam iklim investasi. Dampak yang paling besar adalah perizinan yang tidak jelas, dan terjadi kebingungan bagi mereka yang hendak mengurus investasi. Menurut Ketua Komisi VIDPR RI, Teguh Juwarno, berpendapat bahwa Badan Koordinasi Penanaman Modal merupakan badan pemerintahan yang bergerak dalam hal pengurusan seluruh izin dalam berinvestasi. Pelaksanaan Pelayanan Terpadu Satu Pintu sebelumnya ini dikendalikan oleh Badan Koordinasi Penanaman Modal telah berjalan sesuai dengan semestinya. Jika dilihat menurut aturan yang berlaku, Peraturan Presiden Nomor 24 Tahun 2018 tidak sejalan dengan UndangUndang Penanaman Modal, serta Undang-Undang antar Kementrian, seyogyanya Peraturan Presiden diatas harus sudah tidak diberlakukan lagi, serta proses pengurusan izin yang berbasis online harus dilimpahkan secepatnya kepada Badan Koordinasi Penanaman Modal. ${ }^{14}$

Proses maupun tata cara yang berkaitan dengan teknologi dan informasi tersebut adalah kerterkaitan satu sama lain dan terintegrasi yang bersumber kepada Badan koordinasi Penanaman Modal atau Sistem Pelayanan Informasi dan Perizinan Investasi secara Elektronik/ SPIPISE serta PTSP daerah yang menggunakan sistem siCantik yang dikelola oleh Kementrian Komunikasi dan Informatika. Sistem ini juga didukung oleh sistem berbagai Kementrian dan Lembaga penerbit perizinan, termasuk sistem Indonesia National Single Window (INSW), Sistem Administrasi Hukum Umum Kementrian Hukum dan HAM, serta Sistem Informasi Administrasi Kependudukan Kementrian Dalam Negeri. ${ }^{15}$ Namun terhitung tanggal 2 Januari

14 Parlemen Minta OSS Dihapus, Perizinan Harus Dikembalikan ke BKPM, https://www.cnbcindonesia. com/news/20180821081046-4-29488/parlemenminta-oss-dihapus-perizinan-harus-kembali-ke-bkpm , diakses pada 25 Maret 2019.

15 Mulai 2 Januari 2019, BKPM Ambil Alih 
2019, OSS telah dikelola kembali oleh BKPM. Sekretaris Kementrian Koordinator Bidang Perekonomian mengatakan bahwa walaupun tata cara OSS yang telah dikembalikan kepada Badan Koordinasi Penanaman Modal, agar segala bentuk persengketaan serta permasalahan dalam proses pelaksanaan tata cara yang berbasis online OSS diselesaikan bersamaan dengan Tim Teknis dalam tata cara OSS Kementrian Koordinator Bidang Perekonomian. Perkembangan dan pembentukan tata cara berbasis online termasuk koneksitas, hardware, lisensi software, serta komponen pendukung lainnya. Dan demi berjalannya tata kelola pelaksaan sistem OSS, tanpa dilakukan perubahan serta pertukaran data dari program web, dan saat ini berjalan di infrastruktur penyimpanan data yang bersifat virtual yang tersimpan dan terhimpun di pusat penyimpanan data, serta telah memperoleh sertifikat ISO 27001-2013 tentang Manajemen Keamanan Informasi. ${ }^{16}$

Terdapat 4 (empat) aspek OSS, dan yang dikelola oleh BKPM hanya berupa sistem pengoprasiannya saja. Sebagai informasi tata cara OSS terdiri dari unsur kebijakan dalam rangka mengakselerasi prosedur berusaha yang disesuaikan dan tercantum diPeraturan Presiden Nomor 91 Tahun 2017 disamping itu juga mengenai terbentuknya Satuan Petugas Pengawalan Berusaha da Reformasi Regulasi. Pemberlakuan tata cara pelayanan yang bersifat terpadu ditetapkan dalam Peraturan Presiden Nomor 24 Tahun 2018 juga dalam melakukan penanaman modal untuk melaksanakan usaha yang telah dijalankan, kemudian untuk menyinkronisasi persetujuan untuk melaksanakan usaha berdasarkan tata cara OSS, juga untuk mendapatkan Nomor Izin Berusaha, begitu juga untuk memperpanjang atau merubah izin menjalankan usaha atau izin komersial. ${ }^{17}$

\footnotetext{
Sistem OSS, https://economy.okezone.com/ amp/2018/12/18/320/1992934/mulai-2-januari-2019bkpm-ambil-alih-sistem-oss diakses pada 24 Maret 2019.

16 Awal Tahun 2019, Pelayanan Sistem OSS Mulai Beroprasi di BKPM, https://m.hukumonline.com/ berita/baca/1t5c22daec7446b/awal-tahun-2019pelayanan-sistem-oss-mulai-beroprasi-di-bkpm/ diakses pada 24 Maret 2019

17 Mulai 2 Januari 2019, BKPM Ambil Alih Sistem OSS, https://economy.okezone.com/ amp/2018/12/18/320/1992934/mulai-2-januari-2019bkpm-ambil-alih-sistem-oss diakses pada 24 Maret 2019.
}

Nomor Induk Berusaha (NIB) adalah identitas pelaku usaha yang diterbitkan oleh lembaga OSS setelah pelaku usaha melakukan pendaftaran, dan hal ini tercantum dalam Pasal 1 angka 12 Peraturan Pemerintah Nomor 24 Tahun 2018 tentang Pelayanan Perizinan Berusaha Terintegrasi Secara Elektronik (PP OSS). Perlu untuk diketahui, bahwa sebelum memperoleh izin usaha, izin komersial, dan izin operasional (termasuk pemenuhan persyaratan Izin Usaha dan Izin Komersial atau Operasional), pelaku usaha terlebih dahulu harus mendaftar unutuk mendapatkan NIB melalui sistem OSS. ${ }^{18}$ Sistem OSS digunakan untuk memperoleh izin sebagai berikut: $^{19}$ (1) Nomor Izin Berusaha (NIB); (2) Izin Usaha; (3) Izin Komersial dan Operasional; dan (4) Rencana Penggunaan Tenaga Kerja Asing (RPTKA).

Berdasarkan Pasal 1 angka 12 PP OSS, NIB adalah identitas pelaku usaha yang diterbitkan oleh Lembaga OSS setelah pelaku usaha melakukan pendaftaran. NIB merupakan 13 (tiga belas) digit angka acak yang diberi sebagai pengaman dan disertai dengan tanda tangan elektronik. ${ }^{20}$ Lembaga OSS menerbitkan NIB setelah pelaku usaha melakukan pendaftaran melalui pengisian data sebagaimana dimaksud dalam Pasal 22 PP OSS secara lengkap dan mendapatkan Nomor Pokok Wajib Pajak sebagaimana dimaksud dalam Pasal 23 PP OSS. Yang dimaksud dengan Pelaku Usaha adalah perseoragan atau non perseorangan yang melakukan usaha dan/atau kegiatan pada bidang tertentu. Pelaku usaha perorangan merupakan orang perorangan penduduk Indonesia yang cakap untuk bertindak dan melakukan perbuatan hukum. Sedangkan pelaku usaha non perseorangan terdiri dari perseoran terbatas; perusahaan umum; perusahaan umum daerah; badan hukum lainnya yang dimiliki oleh negara; badan layanan umum; lembaga penyiaran; badan usaha yang didirikan oleh Yayasan; koperasi; persekutuan komanditer (commanditaire vennootschap); persekutuan firma (vennootschap onder firma); dan persekutuan perdata.

Nomor Induk Berusaha adalah identitas tunggal yang akan selalu melekat pada pelaku usahadan juga berisi informasi megenai lokasi usaha/cabang, sehingga dalam melakukan kegiatan

\footnotetext{
$18 \quad$ Pasal 25 ayat (1) PP OSS.

19 Pasal 25 ayat (2) PP OSS.

20 Pasal 24 ayat (1) PP OSS.
} 
usahanya, pelaku usaha yang mempunyai lebih dari satu tempat atau memiliki kantor cabang, maka informasi tersebut akan melekat pada NIB yang sama.

Sistem perizinan usaha terbaru di Indonesia dengan menggunakan sistem satu pintu secara online yaitu OSS harus disesuaikan dengan jenis usaha dan kegiatan yang terdapat dalam Kualifikasi Baku Lapangan Usaha Indonesia (KBLI), KBLI adalah suatu klasifikasi rujukan yang berguna untuk mengklasifikasikan suatu aktifitas atau kegiatan ekonomi yang berada di Negara Republik Indonesia terwujud dari beberapa bentuk tempat pelaksanaan usaha yang dapat dibagi atau dapat ditentukan klasifikasinya melalui beberapa bentuk kegiatan usaha yang memproduksi barang serta memproduksi jasa sebagaimana yang telah diumumkan oleh Badan Pusat Statistik. Hasil dari pengajuan sistem OSS ini memberikan hasil berupa izin NIB tersebut sudah meliputi SIUP dan TDP. Hal ini berkaitan dengan konsep rencana yang diberikan pemerintah yang bertujuan untuk memudahkan dan mempercepat serta meningkatkan dalam menanaman modal berusaha yang dilakukan di Indonesia. Dalam rangka melakukan percepatan dan peningkatan tersebut, pemerintah Indonesia memberlakukan sistem submission secara online(OSS), yakni suatu perizinan berusaha yang diterbitkan atau dikeluarkan oleh OSS untuk dan atas nama mentri, pimpinan lembaga, maupun juga gubernur/bupati/walikota yang ditujukan kepada pelaku usaha yang diberikan melalui suatu sistem elektronik, namun sampai saat ini terdapat perbedaan data PT dalam SABH dalam sistem OSS, hal ini terjadi karena sistem OSS sudah menggunakan KBLI 2017, berbeda dengan SABH yang masih mempergunakan KBLI yang berlaku sebelum 2017, sehingga menimbulkan akibat seperti ketidaksesuaian data yang dimiliki antara Kementrian Hukum dan HAM dengan Kementrian Koordinator Bidang Perekonomian. Ketidaksesuaian ini menimbulkan dampak dengan ditolaknya Nomor Izin Berusaha yang ada pada tata cara OSS yang berlaku.

Perlu dilakukan beberapa penyesuaian dalam diberlakukannya sistem OSS, yakni mengenai perubahan tentang Klasifkasi Baku Lapangan Usaha Indonesia terhadap Perseoan Terbatas yang sudah memiliki dan memperoleh surat keterangan sah pendirian badan usaha yang dikeluarkan oleh
Kementrian Hukum dan Hak Asasi Manusia, yang kemudian perlu diadakan penyesuaian dengan KBLI yang digunakan oleh Kementrian Koordinator Bidang Perkonomian Cq. Lembaga OSS. Sampai dengan sekarang, terjadi ketidaksinkronan data mengenai Perseroan Terbatas yang berada di Sistem Administrasi Badan Hukum dengan sistem OSS yang dimiliki oleh Kementrian Bidang Perekonomian, hal ini terjadi karena sistem OSS yang dimiliki oleh Kementrian Bidang Perekonomian sudah mengacu kepada KBLI 2017, sedangkan SABH masih mempergunakan KBLI yang berlaku sebelum 2017.

Hal tersebut diatas menimbulkan adanya suatu ketidaksesuaian antara data yang dimiliki oleh Kementrian Koordinator Bidang Perekonomian dengan data yang dimiliki oleh Kementrian Hukum dan Hak Asasi Manusia, dan berdampak kepada proses untuk mendapatkan Nomor Induk Berusaha yang ada pada tata cara OSS tidak dapat dilakukan. Untuk dijadikan suatu informasi dan pengetahuan bersama, Kualifikasi Baku Lapangan Usaha Indonesia atau yang disingkat dengan KBLI adalah klasifikasi rujukan yang dipergunakan untuk mengklarifikasi aktifitas atau kegiatan dalam bidang eknomi yang berada di Indonesia yang terbagi menjadi beberapa bentuk lapangan usaha dan juga bidang usaha yang dapat diklasifikasi melalui hasil produksi atau outpu produksi dari jenis kegiatan ekonomi, baik berupa jasa maupun barang yang dikeluarkan oleh BPS.

Solusi dalam menyelesaikan masalah perbedaan penggunaan KBLI tersebut, Kementrian Hukum dan HAM RI Cq. Lembaga OSS, akan dilakukan pelaksanaan proses dan penerbitan NIB untuk Perseroan Terbatas dengan menggunakan KBLI 2017 dalam hal maksud dan tujuan kegiatan usaha perseroan terbatas tersebut, namun hal tersebut dilakukan dengan catatan bahwa dalam jangka satu (1) tahun, perseroan terbatas tersebut harus melakukan penyesuaian sesuai dengan ketentuan-ketentuan yang diatur dalam peraturan Perundang-Undangan Nomor 40 Tahun 2007 tentang Perseroan Terbatas. Pelaksanaanya dilakukan melalui mekanisme perubahan anggaran dasar Perseroan sebagaimana yang telah diatur dan ditentukan didalam Pasal 21 ayat (2) UUPT Nomor 40 Tahun 2007 yang berisikan tentang pengaturan perubahan tujuan maupun perubahan anggaran dasar harus dilakukan dengan mendapatkan persetujuan dari Mentri Hukum dan HAM. 
Badan Koordinasi Penanaman Modal sangat memerlukan profesi notaris untuk melegalkan atau mengesahkan akta pendirian badan usaha, sebagai contoh dalam pendirian perseroan terbatas, menurut Undang-Undang Perseroan Terbatas (UUPT) harus mengikuti langkahlangkah yang ditentukan sebagaimana didalam UUPT. Pembuatan akta pendirian PT dilakukan di hadapan notaris, perjanjian pendirian PT yang dilakukan oleh pendiri dituangkan kedalam suatu akta notaris yang dilakukan oleh para pendiri badan usaha/ perseroan terbatas tersebut yang kemudian disebut dengan Akta Pendirian. Pada dasarnya, Akta Pendirian ini mengatur beberapa hal berupa berbagai macam hak-hak dan kewajiban dari para pendiri pendiri badan usaha dalam melakukan pengelolaan dan dalam menjalankan kegiatan badan usaha tersebut. ${ }^{21}$ Dalam Perseroan Terbatas, disebut sebagai Anggaran Dasar Perseroan, yang berisi hak-hak dan kewajiban. Hal ini sesuai dengan apa yang sudah tercantum dalam Pasal 8 ayat (1) UUPT. ${ }^{22}$

Profesi notaris dalam menjalankan tugasnya berfungsi membuat suatu alat bukti sebagaimana yang diinginkan oleh para pihak yang terkait dalam alat bukti tersebut dalam melakukan suatu tindakan hukum tertentu, serta alat bukti yang dimaksud dalam ranah hukum perdata. Notaris dalam membuat suatu akta, harus berdasarkan permintaan yang diajukan oleh para pihak yang menghadap, tanpa adanya permintaan dari para pihak, notaris tidak akan mengeluarkan atau membuat akta apapun. Pembuatan akta yang dilakukan oleh Notaris tersebut juga dilakukan berdasarkan alat bukti atau keterangan dan/ atau juga pernyataan yang diperoleh notaris dari para pihak yang selanjutnya diterangkan atau juga dinyatakan serta diperlihatkan kepada atau dihadapan notaris tersebut, kemudian notaris akan membuat akta notaris secara lahiriah, formil dan materil.

Kewenangan dan kedudukan notaris untuk membuat akta notaris sangatlah penting untuk membantu terciptanya kepastian dan perlindungan hukum bagi masyarakat, hal ini disebabkan kedudukan dan kewenangan notaris berada dalam ranah prefentif atau ranah pencegahan atas

21 Abdul Kadir Muhammad, Pengantar Hukum Perusahaan, Bandung: PT Citra Aditya Bakti, 1995, hlm.79.

22 Lihat Undang-Undang Nomor 40 Tahun 2007 tentang Perseroan Terbatas. terjadinya masalah hukum. Akta otentik yang dibuat oleh notaris merupakan suatu bingkai perbuatan hukum yang berada dalam ranah hukum perdata yang dilakukan oleh masyarakat yang kedepannya akta terbut dapat dipergunakan sebagai alat bukti yang sempurna di pengadilan. GHS Lumban Tobing berpendapat bahwa pada hakekatnya notaris merekam atau mengkonstantir perbuatan hukum para pihak yang berkempentingan dalam bentuk tertulis. ${ }^{23}$ Akta notaris dibuat denga tujuan agar para pihak yang memiliki kepentingan dalam melakukan perbuatan hukum dapat dituangkan dalam sebuah akta notaris atau akta otentik yang dapat dipergunakan sebagai alat bukti yang kuat dan sempurna. Oleh karenanya, pembuatan akta notaris atau akta otentik harus dilakukan berdasarkan dalam Pasal 1868 KUH Perdata, serta berdasarkan prosedur yang telah ditetapkan, seperti memenuhi ketentuan bentuk akta notaris yang terdiri dari awal akta, badan akta dan penutup/ akhir akta sebagaimana yang telah dinyatakan dan juga sesuai dengan ketentuan Pasal 38 UndangUndang Nomor 30 Tahun 2004 tentang Jabatan Notaris.

\section{Kesimpulan}

Amanat Pancasila dan Undang-Undang Dasar yang menyatakan bahwa tujuan negara diantaranya adalah memajukan kesejahteraan umum dan menciptakan kepastian hukum, negara mewujudkannya dengan diantaranya membuat UU-ITE. Implikasi yuridis yang timbul dari UUITE terhadap Notaris/PPAT telah dinyatakan dalam Pasal 5 ayat (4) hurufd UU ITE. Fungsi kedudukan dan kewenangan notaris dalam membantu dan menciptakan kepastian serta perlindungan hukum bagi masyarakat dinilai sangat penting. Hal ini terjadi karena akta notaris yang dibuat berdasarkan kewenangan notaris berada dalam ranah prefentif, akta notaris ini merupakan suatu bentuk pecegahan apabila terjadi masalah hukum. Akta otentik yang dibuat oleh notaris merupakan suatu bingkai perbuatan hukum yang berada dalam ranah hukum perdata yang dilakukan oleh masyarakat yang kedepannya akta terbut dapat dipergunakan sebagai alat bukti yang sempurna di pengadilan, sebagaimana yang ditetapkan dalam Undang-Undang Nomor 2 Tahun 2014 tentang perubahan atas Undang -Undang Nomor 30 Tahun 2004 tentang Jabatan Notaris.

23 GHS Lumban Tobing, Op. Cit, hlm 38. 
Profesi notaris dalam menjalankan tugasnya berfungsi membuat suatu alat bukti sebagaimana yang diinginkan oleh para pihak yang terkait dalam alat bukti tersebut dalam melakukan suatu tindakan hukum tertentu, serta alat bukti yang dimaksud dalam ranah hukum perdata. Notaris dalam membuat suatu akta, harus berdasarkan permintaan yang diajukan oleh para pihak yang menghadap, tanpa adanya permintaan dari para pihak, notaris tidak akan mengeluarkan atau membuat akta apapun. Pembuatan akta yang dilakukan oleh Notaris tersebut juga dilakukan berdasarkan alat bukti atau keterangan dan/ atau juga pernyataan yang diperoleh notaris dari para pihak yang selanjutnya diterangkan atau juga dinyatakan serta diperlihatkan kepada atau dihadapan notaris tersebut, kemudian notaris akan membuat akta notaris secara lahiriah, formil dan materil, seperti dalam pembuatan perizinan terbaru yang diberlakukan di Indonesia dengan menggunakan sistem satu pintu secara online, yakni OSS yang jenis usaha dan kegiatannya terdapat dalam KBLI. Hasil dari pengajuan sistem OSS ini memberikan izin berupa NIB yang sudah meliputi SIUP dan TDP. Juga saat ini terjadi suatu perbedaan data mengenai Perseroan Terbatas dalam SABH yang masih menggunakan KBLI sebelum 2017 dengan sistem OSS yang sudah mengunakan KBLI 2017, sehingga mengakibatkan terjadinya perbedaan data yang dimiliki oleh Kementrian Hukum dan Hak Asasi Manusia dan Kementrian Koordinator Bidang Perekonomian, sehingga menimbulkan suatu dampak tidak dapat dilakukan proses penerbitan NIB dalam sistem OSS, maka semakin jelas peran profesi notaris di Era Industrialisasi dalam perspektif transendensi Pancasila ini.

\section{Daftar Pustaka}

Abdul Kadir Muhammad, Pengantar Hukum Perusahaan, Bandung: PT Citra Aditya Bakti, 1995.

Arimukti Wibowo dkk, Kerangka Hukum Digital Signature dalam Elektronic Commerce, disampaikan dalam seminar Masyarakat Telekomunikasi Indonesia Pusat Ilmu Komputer, Universitas Indonesia, Juni, 1999.

Habib Adjie, Hukum Notaris di Indonesia-Tafsiran
Tematik terhadap UU No. 30 Tahun 2004 tentang Jabatan Notaris, Bandung: PT. Refika Aditama, 2008.

http://www.definisi-pengertian.com/2015/05/ definisi-pengertian-kesejahteraan-rakyat. html, diakses pada 25 Maret 2019.

https://amp.katadata.co.id/berita/2018/06/04/ bkpm-belum-siap-kemenko-ekonomitangani-izin-online-terintegrasi diakses pada 24 Maret 2019.

h t t p s: / / e conomy.okezone.com/ amp/2018/12/18/320/1992934/mulai-2januari-2019-bkpm-ambil-alih-sistem-oss

https://m.hukumonline.com/berita/baca/ 1t5bb4adade68803/simak-ulasan-notarissoal-perbedaan-oss-ptsp-ahu-onlinedan-sisminbakum diakses pada 25 Maret 2019.

https://m.hukumonline.com/berita/baca/ $1 \mathrm{t} 5 \mathrm{c} 22 \mathrm{daec} 7446 \mathrm{~b} / \mathrm{awal}$-tahun-2019pelayanan-sistem-oss-mulai-beroprasi-dibkpm/ diakses pada 24 Maret 2019

h t t p s://www.cnbcindonesia.com/ news/20180821081046-4-29488/parlemenminta-oss-dihapus-perizinan-haruskembali-ke-bkpm ,

Kitab Undang-Undang Hukum Perdata.

Liliana Tegjosaputro, Tantangan Praktek Kenotariatan dalam Menghadapi Revolusi Industri 4.0, bahan ajar Universitas 17 Agustus 1845, Semarang.

Peraturan Pemerintah Nomor 24 Tahun 2018 tentang Pelayanan Perizinan Berusaha Terintegrasi Secara Elektronik.

Robert B. Seidman dan William J. Chambless, Law, Order, and Power, printed in United States of America, Published Stimulant in Canada Library of Cobress Catalog Cars No.78-111948.

Tan Thong Kie, Studi Notariat, Beberapa Mata Pelajaran dan Serba-serbi Praktek Notaris, (Jakarta: PT. Ichitar Baru Van Hoeve, 2007)

Undang-Undang Nomor 11 Tahun 2008 tentang Informasi dan Transaksi Elektronik.

Undang-Undang Nomor 2 Tahun 2014 tentang 
perubahan atas Undang-Undang Nomor 30 Tahun 2004 tentang Jabatan Notaris.

Undang-Undang Nomor 30 Tahun 2004 tentang Jabatan Notaris.

Undang-Undang Nomor 40 Tahun 2007 tentang Perseroan Terbatas. 